\title{
Sharing Economy and Fast Fashion \\ (Sustainability and virtual consumer behavior: A review and research agenda)
}

\section{AUTHOR}

Ramon Ruiz-Navarro

PhD Doctoral student

rruizn@uoc.edu

ORCID-ID: 0000-0002-0140-3480

\section{CO-AUTHORS}

PhD Carolina Hintzmann

ORCID: 0000-0003-0707-6115

chintzmann@uoc.edu

$\mathrm{PhD}$ August Corrons

ORCID: 0000-0003-3629-6475

acorrons@uoc.edu

\author{
UNIVERSITAT OBERTA DE CATALUNYA \\ www.uoc.edu \\ Economics and Business Studies \\ Avinguda del Tibidabo, 39-43 \\ 08035 Barcelona - Spain
}

\begin{abstract}
:
The market offers the sharing economy potential access to renting or exchanging fashion through virtual networks, and this opens-up ways to investigate the perceptions of virtual consumers about these types of products and what factors affect their intentions to access through of this type of networks (social networks, mobile applications, or collaborative platforms). This is a theoretical work that, through a literature review, have the objective to contextualize the importance of consumer behavior towards a more sustainable economy, emphasizing the sharing economy as an alternative to fast fashion. The behavior of people towards the phenomenon of the sharing economy in general is very important, and particularly the behavioral intention related to technological networks (virtual textile fashion networks) could be decisive in their use, and contribute to the reduction of pollution, damage to the environment and the overconsumption of natural resources (water, energy, materials) involved in making clothing. This work is approached from a perspective that can help to promote the fashion exchange, examining the antecedents of the intention of consumers to participate in virtual fashion networks. Consequently, consumer behavior can make a difference by helping to extend the life of clothing by sharing or reusing it. For this reason, selling or buying second-hand clothing through online platforms, donating to charities, or giving to friends has the environmental benefit of extending its useful life and is better than storing in the closet and not wearing.
\end{abstract}

Keywords: Sharing economy, Fast fashion, Consumer behavior, Environment and sustainability, Ecommerce, COVID-19. 


\section{Introduction}

The globalization of the economy and knowledge, the revolution towards the digital age and the evolution of demand, together with the high rate of technological change and the continuous and progressive liberalization of markets, are causing the textile sector to face an important process of transformation and adaptation to respond to the new challenges that arise. In addition, the preservation of the environment is becoming more and more aware in society, "the textile sector cannot ignore this requirement", and must adapt its processes to the new paradigms, since it is one of the major contributors to deterioration of the environment. The main environmental impacts related to this industry have to do with the wastewater it generates and the chemical load it contains.

Textiles in general and particularly clothing are a fundamental part of everyday life and an important sector in the world economy (MacArthur, 2017). It is difficult to imagine a world without textiles. Almost everyone wears clothes, almost all the time, and many are an important expression of individuality.

Fashion is among the most polluting industries in the world; it requires huge amounts of raw materials, creates considerable levels of pollution (Linden, 2016), leaves a significant carbon footprint and generates an alarming volume of waste.

Fast fashion is being widely criticized either due to environmental or human rights issues and is having a negative impact on the world. Mass production generates tons of waste (Mora \& Rouzaut, 2018), has a great environmental impact and affects the poor working conditions of many people. The production and consumption of fast fashion is the source of far-reaching environmental consequences, it is estimated that every year 100 billion pieces of clothing are manufactured. Fashion styles change very quickly, clothes are quickly replaced by cheap, poorly made items, and with low quality materials. In addition, unwanted pieces generate a lot of waste that ends up in landfills, and the pollution they generate is transforming rivers and oceans, as fish and other aquatic species ingest small synthetic fragments when they feed (Cameron, 2015). It should be noted that this accumulation of small fragments is causing a significant environmental impact on marine life.

Fast fashion has been considered a trend both from the perspective of the consumer economy and from the perspective of caring for and respecting the environment, so the intention of consumer behavior should focus on both perspectives. On the one hand, the user receives information from companies and other consumers (also through social networks), and on the other hand, based on this information the consumer, after analyzing it, will decide whether to act for the benefit of both society and the environment, selling or sharing own items through different sharing economy platforms.

Consequently, alternatives to the fast fashion system are emerging, and a viable alternative could be the sharing economy (Cañigueral, 2013), i.e., buy less and share more, but not necessarily consume less (Botsman \& Rogers, 2010). The concept of sharing economy is a growing trend worldwide, which is now beginning to be part of everyday life through usage of different internet applications. Some companies have already adapted to this system (Sutherland \& Jarrahi, 2018), such as Blablacar, Uber, Airbnb, Getaround, Vinted and many more. In addition, fashion brands are also looking for new alternative forms of growth: "the second-hand market", which is estimated to exceed fast fashion sales in 2028 (Heuritech \& Gosselin, 2019), and with the possibility of a "retail apocalypse" department stores, fashion retailers and resale platforms have shown increasing interest in the "preowned" fashion market.

Sharing economy model argues that renting is better than owning (cars, vacation homes or even clothes). This system is taking over different markets and one of them is fashion (Botsman \& Rogers, 2010). It should be emphasized that the model of sharing economy in the fashion sector through virtual networks could be an opportunity that helps the sustainability of economic development, as 
tons of clothes go to the landfill every day and rent or share garments could help move towards a more sustainable economy.

Human beings have ability to reason and adapt (Stebbins, 1969; E. Stern, 2017), and therefore must be able to take initiatives to promote alternatives that allow them to share and collaborate with each other, be more supportive and have more consideration and care for the environment. The sharing economy could be a solution, as it is characterized by greater citizen participation, which through virtual networks, puts them in touch to share and / or sell services and goods.

The followers of this system of sharing economy are especially those who belong to a generation that was born with technology, such as millennials (Sorensen \& Johnson Jorgensen, 2019) and Z generation, as this system revolves around Information Communication Technology (ICT), web platforms or smartphones applications (mobile App's), etc. Millennials and Z generation can be considered as the inhabitants of the digital world or practical netizens because they dominate electronic technology and its gadgets (Camacho-Moya, 2017), "they are current and future consumers'. As an example, " $58 \%$ of London millennials are already interested in renting clothes" (Duff, 2019). That is why the behavioral intention (Ajzen \& Fishbein, 1980) of people with a behavior related to technological networks, like virtual textile fashion networks (Lee \& Chow, 2020), could be decisive in their use. That is why the behavioral intention (Ajzen \& Fishbein, 1980) of people with a behavior related to technological networks could be decisive in their use, as could be the case of virtual textile fashion networks (Lee \& Chow, 2020).

However, despite the potential of the market to access to rent or share textile fashion through virtual networks, little is known about the perception of consumers about this type of product and what factors influence their intentions to access them through of these networks. Therefore, these findings could provide a better perspective to help understand and drive fashion model exchange by examining the antecedents that shape consumer intention that determines their participation in textile fashion virtual networks. It would be appropriate to examine behavior considering that attitude, subjective norm and perceived control are the antecedents of behavioral intention (Ajzen, 1991).

The main objective of this work, through a review of the literature, is to contextualize the importance of fashion consumer behavior towards a more sustainable economy, emphasizing the sharing economy as an alternative to fast fashion through virtual networks, and therefore also highlights the use that consumers make of new technologies (social networks, mobile applications, or collaborative platforms). The specifics objectives are no others than to show the need to contribute to the reduction of pollution, damage to the environment and the overconsumption of natural resources (water, energy, or materials) involved in the manufacture of clothing. All this linked to consumer behavior, innovation, e-commerce, sharing economy, and the entrepreneurship of the social and solidarity economy.

The consolidation of the shared economy in the fashion industry could offer social, economic, and environmental benefits, so this research also wants to highlight the convenience of identifying and analyzing the different beliefs of people with similar behaviors using this type of network and virtual fashion platforms, and which, due to the confinement of COVID-19, appears to have increased exponentially. 


\section{Methodology}

The review approach adopted in this paper was concept-centric (Webster \& Watson, 2002), meaning that it followed a set of terms (sharing economy, fashion / fast fashion, consumer behavior), rather than a particular research perspective or academic discipline. The review was done in two phases: an initial exploratory investigation, followed by a more extensive guided search. In the first phase of the review, the terms were investigated to identify a first set of featured articles. Because the literature on this area is relatively new and interdisciplinary, the research was not based on a single set of journals or a single research area, but rather it followed these concepts on various research / areas in which they have sparked interest, ranging from market research and consumer behavior to technologies and sustainability.

This first search mainly focused on articles that attempted to describe essential elements, so most of the articles collected in this first search were those that provided a definition of sharing or collaborative economy and fashion / fast fashion. As it is an emerging research area, the motivation for this first data collection was to understand these concepts and generate what are called "input terms" (Bates, 1976) to carry out a search and review of the literature (Table-1).

Table: 1 - Terms and concepts extracted from the exploratory search

\begin{tabular}{ll}
\multicolumn{2}{c}{ Terms and concepts extracted from the exploratory search } \\
\hline $\begin{array}{l}\text { Sharing Economy / Collaborative Economy / } \\
\text { Collaborative Consumption }\end{array}$ & (Belk, 2014; Botsman \& Rogers, 2010; Cañigueral, 2016; \\
Fast Fashion / Fashion & Sutherland \& Jarrahi, 2018) \\
Internet / Technology & (Botsman \& Rogers, 2010; Cameron, 2015; Miller, 2013) \\
& (Belk, 2014; Botsman \& Rogers, 2010; Cañigueral, 2016; \\
Behavior / Consumer Behavior & Miller, 2013; Sutherland \& Jarrahi, 2018) \\
& (Belk, 2014; Botsman \& Rogers, 2010; Cameron, 2015; \\
Digital Commerce / Ecommerce / Platforms & Miller, 2013; Sutherland \& Jarrahi, 2018) \\
& (Belk, 2014; Botsman \& Rogers, 2010; Cañigueral, 2016; \\
Environment / Sustainability & Sutherland \& Jarrahi, 2018) \\
& (Belk, 2014; Botsman \& Rogers, 2010; Cameron, 2015; \\
& Cañigueral, 2016; Miller, 2013; Sutherland \& Jarrahi, 2018)
\end{tabular}

Using the terms gathered through the first search, a second set of searches was performed to collect a body of articles which would be broad enough to express the main research agendas. The search has been carried out in bibliographic databases (such as Web of Science, Wiley Online Library, SCOPUS, among others), using algorithms to perform the search (Crossan \& Apaydin, 2010; Tranfield, Denyer, \& Smart, 2003), and, on the other hand, manually, through Google / Google Scholar and the Internet in journals, magazines, and other organizations, in order to collect the latest information.

All the selected articles that were considered most relevant for this work were incorporated into the Mendeley bibliographic manager and thus be able to carry out full-text searches, make annotations and highlight the finally selected documents. The second round helps to consolidating and solidifying the terms and concepts which had been established (Table-2). In addition, some articles from the selected bibliography were also incorporated, since they referred to highly relevant literature, as an example, theories about planned behavior. 
Source: Journals/Web/Press

Accenture.com

Advances in Experimental

Social Psychology

Appareltextilesourcing.com

Australian Feminist Studies

Bard Digital Commons

Book: Alianza Editorial

Canadian Review of Sociology

Clothing and Textiles Research

Journal

Computers in Human Behavior

Computing.es

Consumer Behavior and

Marketing

Consumocolaborativo.com

E-book: Harpers Collins

E-book: SkytsEngel

Ellen Macarthur Foundation

Encyclopedia of Applied

Psychology

European Journal of Marketing

European Journal of Marketing

Heuritech.com

Inforges.es

Information and Management

Information Systems Research

ING International Survey

ING International Survey

International Journal of Fashion

Design, Technology and

Education

International Journal of

Information Management

International Journal of Retail \&

Distribution Management

Journal of Business Research

Journal of Business Research

Journal of Business Research

Journal of Cleaner Production

Journal of Electronic Commerce in Organizations

Journal of Experimental Social Psychology

Journal of Fashion Marketing

and Management

Journal of Fashion Marketing

and Management

Journal of Retailing and

Consumer Services

Journal of Social Issues

Journal of Social Issues

McKinsey \& Company

Modaes.es

MurciaEconomía.com

Organizational Behavior and

Human Decision Processes

Oxford University - Public

Opinion Quarterly

Psychology \& Health

Renttherunway.com

Revista Europea de Direccion y

Economia de la Empresa
Literature review references

Accenture. (2020). Covid-19: Cómo actuar hoy, qué hacer mañana. Cambio de canal: priorizando el e-commerce. Gestionando el impacto económico y humano del COVID-19.

Schwartz, S. H. (1992). Universals in the content and structure of values: Theoretical advances and empirical tests in 20 countries.

Duff, C. (2019). First Cars, Now Clothing? Fashion in the Sharing Economy - Apparel Textile Sourcing Trade Shows.

Brooks, A. (2016). Clothing Poverty: The Hidden World of Fast Fashion and Second-Hand Clothes.

Linden, A. R. (2016). An Analysis of the Fast Fashion Industry.

Castells et al., M. (2017). Otra economía es posible : cultura y economía en tiempo de crisis.

Stebbins, R. A. (1969). Studying the Definition of the Situation: Theory and Field Research Strategies.

Kim, Y.-K., Kim, E. Y., \& Kumar, S. (2003). Testing the Behavioral Intentions Model of Online Shopping for Clothing.

Herrero, A., \& Rodríguez del Bosque, I. (2008). The effect of innovativeness on the adoption of B2C e-commerce: A model based on the Theory of Planned Behaviour.

Armelini, G. (2006). Internet convierte el boca-oreja en el eWom, una poderosa herramienta de marketing.

Chivandi, A., Olorunjuwon, M. S., \& Muchie, M. (2019). Social Media, Consumer Behavior, and Service Marketing.

Cañigueral, A. (2013). Chicfy marketplace para vender tu ropa y comprarla a otras chicas.

Botsman, R., \& Rogers, R. (2010). Whats mine is yours: the rise of collaborative consumption.

Skytte, C. (2014). THE COMSUMER - Sharing Economy in Denmark.

MacArthur, E. (2017). A new textiles economy: redesigning fashion's future.

Solomon, M. R. (2004). Consumer Psychology

Hansen, T., \& Møller Jensen, J. (2009). Shopping orientation and online clothing purchases: the role of gender and purchase situation.

Kim, E. Y., \& Kim, Y. (2004). Predicting online purchase intentions for clothing products

Heuritech, \& Gosselin, V. (2019). When the sharing economy is challenging fast fashion.

Inforges. (2020). El ecommerce en tiempos del COVID-19.

Ahn, T., Ryu, S., \& Han, I. (2007). The impact of Web quality and playfulness on user acceptance of online retailing.

Taylor, S., \& Todd, P. A. (1995). Understanding Information Technology Usage: A Test of Competing Models.

ING. (2015). European sharing economy to grow by a third in the next 12 months.

ING. (2019). Circular economy : Consumers seek help. ING International Survey • Consumer Attitudes towards the Circular Economy.

Joyner Armstrong, C. M., \& Park, H. (2017). Sustainability and collaborative apparel consumption: putting the digital 'sharing' economy under the microscope.

Sutherland, W., \& Jarrahi, M. H. (2018). The sharing economy and digital platforms: A review and research agenda.

Tong, X. (2010). A cross-national investigation of an extended technology acceptance model in the online shopping context.

Belk, R. (2014). You are what you can access: Sharing and collaborative consumption online.

Benoit, S., Baker, T. L., Bolton, R. N., Gruber, T., \& Kandampully, J. (2017). A triadic framework for collaborative consumption (CC): Motives, activities and resources \& capabilities of actors.

Roos, D., \& Hahn, R. (2017). Does shared consumption affect consumers' values, attitudes, and norms? A panel study.

Gullstrand Edbring, E., Lehner, M., \& Mont, O. (2016). Exploring consumer attitudes to alternative models of consumption: Motivations and barriers.

Cheung, C. M. K., Chan, G. W. W., \& Limayem, M. (2005). A Critical Review of Online Consumer Behavior

Ajzen, I., \& Fishbein, M. (1980). Understanding attitudes and predicting social behavior.

Miller, K. (2013). Hedonic customer responses to fast fashion and replicas.

Nash, J. (2018). Exploring how social media platforms influence fashion consumer decisions in the UK retail sector.

Lee, S., \& Chow, P.-S. (2020). Investigating consumer attitudes and intentions toward online fashion renting retailing.

Schwartz, S. H. (1994). Are There Universal Aspects in the Structure and Contents of Human Values?

Stern, P. C. (2000). New Environmental Theories: Toward a Coherent Theory of Environmentally Significant Behavior.

McKinsey\&Company. (2019). The State of Fashion 2020.

Moda.es. (2018). La ONU califica la industria del 'fast fashion' como "emergencia medioambiental"

Murciaeconomía. (2020). La importancia del eCommerce durante el Covid-19.

Ajzen, I. (1991). Theory of planned behavior. Social Psychologyvolume I: Social Cognition and Social Perception

Katz, D. (1960). The Functional Approach to the Study of Attitudes.

Ajzen, I. (2011). The theory of planned behaviour : Reactions and reflections.

Renttherunway. (2019). Rent the Runway - Rent Designer Dresses, Apparel \& Accessories

Matute Vallejo, J., Polo Redondo, Y., \& Utrillas Acerete, A. (2015). Las características del boca-oído electrónico y su influencia en la intención de recompra online. 


\begin{tabular}{|c|c|}
\hline Social Sciences & $\begin{array}{l}\text { Sorensen, K., \& Jorgensen, J. J. (2019). Millennial perceptions of fast fashion and second-hand clothing: An } \\
\text { exploration of clothing preferences using Q methodology. }\end{array}$ \\
\hline Sustainability & $\begin{array}{l}\text { Clausen, J., Blättel-Mink, B., Erdmann, L., \& Henseling, C. (2010). Contribution of Online Trading of Used Goods } \\
\text { to Resource Efficiency: An Empirical Study of eBay Users. }\end{array}$ \\
\hline $\begin{array}{l}\text { Sustainable Production and } \\
\text { Consumption }\end{array}$ & $\begin{array}{l}\text { Lang, C., \& Joyner Armstrong, C. M. (2018). Collaborative consumption: The influence of fashion leadership, need } \\
\text { for uniqueness, and materialism on female consumers' adoption of clothing renting and swapping. }\end{array}$ \\
\hline The Service Industries Journal & $\begin{array}{l}\text { Luque-Martínez, T., Castañeda-García, J. A., Frías-Jamilena, D. M., Muñoz-Leiva, F., \& Rodríguez-Molina, M. A. } \\
\text { (2007). Determinants of the Use of the Internet as a Tourist Information Source. }\end{array}$ \\
\hline The Textile Institute & Heuer, M., \& Becker-Leifhold, C. (2018). Eco-friendly and fair : fast fashion and consumer behaviour. \\
\hline UNECE.org & UNECE. (2018). Fashion and the SDGs: what role for the UN? \\
\hline Universidad de Cantabria & $\begin{array}{l}\text { Herrero, A. (2005). El proceso de adopción de nuevos sistemas de venta: aplicación al comercio electrónico entre } \\
\text { particulares y empresas. }\end{array}$ \\
\hline Universidad de Guadalajara & $\begin{array}{l}\text { Camacho-Moya, V. (2017). La Influencia Del Marketing Digital En Los Millennials Mexicanos Para Fomentar El } \\
\text { Consumismo De Moda Rápida. }\end{array}$ \\
\hline Universidad de Navarra & Mora, E., \& Rouzaut, N. (2018). El impacto de la moda, un desafío para la agenda de la industria textil. \\
\hline Universitat Jaume I & $\begin{array}{l}\text { Corrons, A. (2018). Análisis de la influencia de los valores humanos y las actitudes en el proceso de adopción de } \\
\text { redes virtuales de intercambio no monetario: enfoques actitudinal, motivacional y panárquico. }\end{array}$ \\
\hline Universitat Oberta de Catalunya & Barrullas, J. (2016). El comportamiento del consumidor y las nuevas tendencias de consumo ante las TIC. \\
\hline Universitat Oberta de Catalunya & Cañigueral, A. (2016). Hacia una economía colaborativa «responsable». \\
\hline Wrap.org & WRAP. (2017). Valuing Our Clothes: the cost of UK fashion. \\
\hline
\end{tabular}

The next step was to use the Content Analysis (CA) technique to categorize the articles. Content analysis is a technique for reading and interpreting the content of any kind of communicative documents or messages, and especially written texts (Abela, 2002; Cabero, Loscertales, Aguaded, et al., 2015; Guix Oliver, 2008; Yang, Song, \& Tong, 2017). The technique proposes to follow the following five major phases: pre-analysis, formation of the categorical system, coding, analysis and interpretation, and presentation of the report.

As mentioned above, the articles in this work were selected using different sources of information, such as: scientific journals, specialized fashion websites, press releases and existing surveys, that addressed topics like sharing economy, fast fashion, sustainability, consumer behavior, internet/online shopping, and e-commerce. The selection criteria were based on keywords and phrases contained within the articles and related to the subject under study. Then a categorization was carried out and a word (coding) was assigned to each category to have a better view of the selected literature (Figure-1, Table-3). This categorization has been used to carry out the analysis on which the discussion and the results of the literature review have focused (CA technique was helpful in doing this). The next section presents the main findings of the analysis.

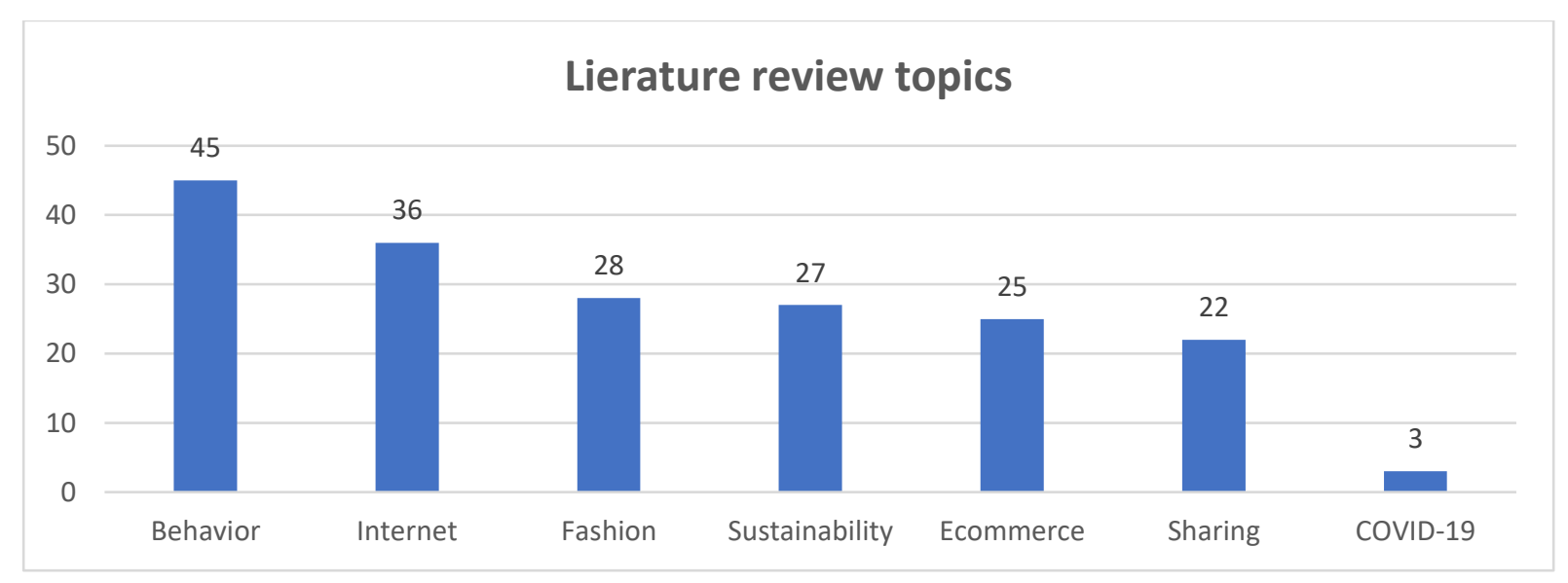

Figure: 1 - Literature review topics 
Table: 3 - Literature review references: articles/topics categorization (following Content Analysis technique)

\begin{tabular}{|c|c|}
\hline \multirow{2}{*}{$\begin{array}{l}\text { Literature review references } \\
\text { Accenture. (2020). Covid-19: Cómo actuar hoy, qué hacer mañana. Cambio de canal: priorizando el e-commerce. Gestionando el } \\
\text { impacto económico y humano del COVID-19. }\end{array}$} & \\
\hline & \\
\hline Ahn, T., Ryu, S., \& Han, I. (2007). The impact of Web quality and playfulness on user acceptance of online retaling. & \\
\hline Ajzen, I. (1991). Theory of planned behavior. Social Psychologyvolume I: Social Cognition and Social Perception & \\
\hline Ajzen I. (2011). The theory of planned behaviour: Reactions and reflections. & \\
\hline Ajzen, I., \& Fishbein, M. (1980). Understanding attitudes and predicting social behavior. & \\
\hline Irmelini, G. (2006). Internet convierte el boca-oreja en el eWom, una poderosa herramienta de marketing. & \\
\hline arrullas, J. (2016). El comportamiento del consumidor y las nuevas tendencias de consumo ante las TIC. & \\
\hline elk, R. (2014). You are what you can access: Sharing and collaborative consumption online. & \\
\hline $\begin{array}{l}\text { Benoit, S., Baker, T. L., Bolton, R. N., Gruber, T., \& Kandampully, J. (2017). A triadic framework for collaborative consumption } \\
\text { (CC): Motives, activities and resources \& capabilities of actors. }\end{array}$ & \\
\hline ootsman, R., \& Rogers, R. (2010). Whats mine is yours: the rise of collaborative consumption. & \\
\hline Brooks, A. (2016). Clothing Poverty: The Hidden World of Fast Fashion and Second-Hand Clothes. & \\
\hline $\begin{array}{l}\text { Camacho-Moya, V. (2017). La Influencia Del Marketing Digital En Los Millennials Mexicanos Para Fomentar El Consumismo } \\
\text { De Moda Rápida. }\end{array}$ & \\
\hline añigueral, A. (2013). Chicfy marketplace para vender tu ropa y comprarla a otras chicas. & \\
\hline Cañigueral A. A. (2016). Hacia una economia colaborativa «responsable». & \\
\hline Castells et al, M. (2017). Otra economia es posible : cultura y economia en tiempo de crisis. & \\
\hline Cheung, C. M. K., Chan, G. W. W., \& Limayem, M. (2005). A Critical Review of Online Consumer Behavior. & \\
\hline $\begin{array}{l}\text { Chivandi, A., Olorunjuwon, M. S., \& Muchie, M. (2019). Social Media, Consumer Behavior, and Service Marketing } \\
\text {. }\end{array}$ & \\
\hline $\begin{array}{l}\text { Clausen, J., Blättel-Mink, B., Erdmann, L., \& Henseling, C. (2010). Contribution of Online Trading of Used Goods to Resource } \\
\text { Efficiency. An Empirical Study of eBay Users. }\end{array}$ & \\
\hline $\begin{array}{l}\text { Corrons, A. (2018). Anâlisis de la influencia de los valores humanos y las actitudes en el proceso de adopciôn de redes virtuales } \\
\text { de intercambio no monetario: enfoques actitudinal, motivacional y panárquico. }\end{array}$ & \\
\hline Juff, C. (2019). First Cars, Now Clothing? Fashion in the Sharing Economy - Apparel Textile Sourcing Trade Shows. & \\
\hline $\begin{array}{l}\text { Gullstrand Edbring, E., Lehner, M., \& Mont, O. (2016). Exploring consumer attitudes to alternative models of consumption: } \\
\text { Motivations and barriers. }\end{array}$ & \\
\hline $\begin{array}{l}\text { Hansen, T., \& Moller Jensen, J. (2009). Shopping orientation and online clothing purchases: the role of gender and purchase } \\
\text { situation. }\end{array}$ & \\
\hline $\begin{array}{l}\text { Herrero, A. (2005). El proceso de adopción de nuevos sistemas de venta: aplicación al comercio electrónico entre particulares y } \\
\text { empresas. }\end{array}$ & \\
\hline $\begin{array}{l}\text { Herrero, A., \& Rodriguez del Bosque, I. (2008). The effect of innovativeness on the adoption of B2C e-commerce: A model } \\
\text { based on the Theory of Planned Behaviour. }\end{array}$ & \\
\hline Heuer, M., \& Becker-Leifhold, C. (2018). Eco-friendly and fair : fast fashion and consumer behaviour. & \\
\hline Heuritech, \& Gosselin, V. (2019). When the sharing economy is challenging fast fashion. & \\
\hline Inforges. (2020). El ecommerce en tiempos del COVID-19. & \\
\hline ING. (2015). European sharing economy to grow by a third in the next 12 months. & \\
\hline $\begin{array}{l}\text { ING. (2019). Circular economy : Consumers seek help. ING International Survey } \bullet \text { Consumer Attitudes towards the Circular } \\
\text { Economy. }\end{array}$ & \\
\hline $\begin{array}{l}\text { Joyner Armstrong, C. M., \& Park, H. (2017). Sustainability and collaborative apparel consumption: putting the digital 'sharing' } \\
\text { economy under the microscope. }\end{array}$ & \\
\hline Katz, D. (1960). The Functional Approach to the Study of Attitudes. & \\
\hline Kim, E. Y., \& Kim, Y. (2004). Predicting online purchase intentions for clothing products. & \\
\hline Kim, Y.-K., Kim, E. Y., \& Kumar, S. (2003). Testing the Behavioral Intentions Model of Online Shoppi & \\
\hline $\begin{array}{l}\text { Lang, C., \& Joyner Armstrong. C. M. (2018). Collaborative consumption. The influence of fashion leadership, need for } \\
\text { uniqueness, and materialism on female consumers' adoption of clothing renting and swapping. }\end{array}$ & \\
\hline Lee, S., \& Chow, P.-S. (2020). Investigating consumer attitudes and intentions toward online fashion renting retailing. & \\
\hline Linden, A. R. (2016). An Analysis of the Fast Fashion Industry. & \\
\hline $\begin{array}{l}\text { Luque-Martinez, T., Castañeda-Garcia, J. A., Frias-Jamilena, D. M., Muñoz-Leiva, F., \& Rodriguez-Molina, M. A. (2007). } \\
\text { Determinants of the Use of the Internet as a Tourist Information Source. }\end{array}$ & \\
\hline MacArthur, E. (2017). A new textiles economy. redesigning fashion's future. & \\
\hline $\begin{array}{l}\text { Matute Vallejo, J., Polo Redondo, Y., \& Utrillas Acerete, A. (2015). Las caracteristicas del boca-oido electrónico y su influencia } \\
\text { en la intención de recompra online. }\end{array}$ & \\
\hline McKinsey\&Company. (2019). The State of Fashion 2020. & \\
\hline Miller, K. (2013). Hedonic customer responses to fast fashion and replicas. & \\
\hline Moda.es. (2018). La ONU califica la industria del 'fast fashion' como "emergencia medioambiental" & \\
\hline Mora, E., \& Rouzaut, N. (2018). El impacto de la moda, un desafio para la agenda de la industria textil. & \\
\hline Murciaeconomia. (2020). La importancia del eCommerce durante el Covid-19. & \\
\hline Nash, J. (2018). Exploring how social media platforms influence fashion consumer decisions in the UK retail sector. & \\
\hline Rentherunway. (2019). Rent the Runway - Rent Designer Dresses, Apparel \& Accessories & \\
\hline Roos, D., \& Hahn, R. (2017). Does shared consumption affect consumers' values, attitudes, and norms? A panel study. & \\
\hline $\begin{array}{l}\text { Schwartz, S. H. (1992). Universals in the content and structure of values: Theoretical advances and empirical tests in } 20 \\
\text { countries. }\end{array}$ & \\
\hline Schwartz, S. H. (1994). Are There Universal Aspects in the Structure and Contents of Human Values? & \\
\hline Skytte, C. (2014). THE COMSUMER - Sharing Economy in Denmark. & \\
\hline Solomon, M. R. (2004). Consumer Psychology & \\
\hline $\begin{array}{l}\text { Sorensen, K., \& Jorgensen, J. J. (2019). Millennial perceptions of fast fashion and second-hand clothing: An exploration of } \\
\text { clothing preferences using Q methodology. }\end{array}$ & \\
\hline Stebbins, R. A. (1969). Studying the Definition of the Situation: Theory and Field Research Strategies. & \\
\hline Stern, P. C. (2000). New Environmental Theories: Toward a Coherent Theory of Environmentally Sigr & \\
\hline Sutherland, W., \& Jarrahi, M. H. (2018). The sharing economy and digital platforms: A review and research agenda. & \\
\hline Taylor, S., \& Todd, P. A. (1995). Understanding Information Technology Usage: A Test of Competing Models & \\
\hline Tong, X. (2010). A cross-national investigation of an extended technology acceptance model in the online & \\
\hline JNECE. (2018). F & \\
\hline P. (2017). Va & \\
\hline
\end{tabular}

\begin{tabular}{|c|c|c|c|c|c|c|c|c|}
\hline Item & Behavior & Internet & Fashion & Sustainability & Ecommerce & Sharing & COVID-19 & Total topics \\
\hline 1 & & $x$ & & & $\mathrm{x}$ & & $\mathrm{x}$ & 3 \\
\hline 2 & $x$ & $x$ & & & $x$ & & & 3 \\
\hline 3 & $\hat{x}$ & & & & & & & 1 \\
\hline 4 & $x$ & & & & & & & 1 \\
\hline 5 & $x$ & & & & & & & 1 \\
\hline 6 & & $x$ & & & & & & 1 \\
\hline 7 & $x$ & $x$ & & & & & & 2 \\
\hline 8 & $x$ & $x$ & & $x$ & $x$ & $x$ & & 5 \\
\hline 9 & & & & & & $\mathrm{x}$ & & 1 \\
\hline 10 & $x$ & $x$ & $x$ & $x$ & $x$ & $x$ & & 6 \\
\hline 11 & $x$ & & $x$ & $x$ & & & & 3 \\
\hline 12 & & $\mathrm{x}$ & $\mathrm{x}$ & & & & & 2 \\
\hline 13 & & $x$ & $x$ & & & $x$ & & 3 \\
\hline 14 & 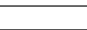 & $x$ & & $x$ & $x$ & $x$ & & 4 \\
\hline 15 & & $x$ & & & & & & 1 \\
\hline 16 & $x$ & $x$ & 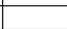 & & $x$ & 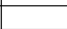 & & 3 \\
\hline 17 & $x$ & $x$ & & $x$ & & & & 3 \\
\hline 18 & $x$ & $x$ & $x$ & $x$ & $x$ & & & 5 \\
\hline 19 & $\mathrm{x}$ & $x$ & & $x$ & $\mathrm{x}$ & $x$ & & 5 \\
\hline 20 & & & $x$ & & & $x$ & & 2 \\
\hline 21 & $\mathrm{x}$ & $\mathrm{x}$ & & $\mathrm{x}$ & $\mathrm{x}$ & $\mathrm{x}$ & & 5 \\
\hline 22 & $\mathrm{x}$ & $\mathrm{x}$ & $x$ & $\mathrm{x}$ & $\mathrm{x}$ & & & 5 \\
\hline 23 & $x$ & $x$ & & & $\mathrm{x}$ & & & 3 \\
\hline 24 & $\mathrm{x}$ & $\mathrm{x}$ & & & $\mathrm{x}$ & & & 3 \\
\hline 25 & $x$ & $x$ & $x$ & $x$ & $x$ & $x$ & & 6 \\
\hline 26 & & & $x$ & $x$ & & $\mathrm{x}$ & & 3 \\
\hline 27 & 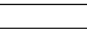 & 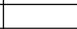 & & & $x$ & & $x$ & 2 \\
\hline 28 & 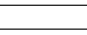 & & $x$ & $x$ & & $x$ & & 3 \\
\hline 29 & $x$ & & $\mathrm{x}$ & $x$ & & $x$ & & 4 \\
\hline 30 & $x$ & $\mathrm{x}$ & $\mathrm{x}$ & $x$ & $x$ & $x$ & & 6 \\
\hline 31 & $x$ & & & & & & & 1 \\
\hline 32 & $x$ & $x$ & $x$ & 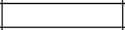 & $x$ & 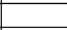 & & 4 \\
\hline 33 & $x$ & $x$ & $x$ & 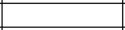 & $x$ & 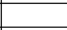 & & 4 \\
\hline 34 & $x$ & & $\mathrm{x}$ & $x$ & & $x$ & & 4 \\
\hline 35 & $x$ & $x$ & $x$ & $x$ & $x$ & $x$ & & 6 \\
\hline 36 & $x$ & & $x$ & $x$ & & & & 3 \\
\hline 37 & $\mathrm{x}$ & $\mathrm{x}$ & & & $\mathrm{x}$ & & & 3 \\
\hline 38 & $x$ & $x$ & $\mathbf{x}$ & $x$ & & $x$ & & 5 \\
\hline 39 & $\mathbf{x}$ & $\mathrm{x}$ & & & $\mathrm{x}$ & & & 3 \\
\hline 40 & $x$ & $x$ & $x$ & $x$ & $x$ & & & 5 \\
\hline 41 & $x$ & $x$ & $x$ & & & & & 3 \\
\hline 42 & & & $x$ & $x$ & & & & 2 \\
\hline 43 & $x$ & & $x$ & $x$ & & & & 3 \\
\hline 44 & & $x$ & & & $x$ & & $x$ & 3 \\
\hline 45 & $x$ & $x$ & $x$ & & & $x$ & & 4 \\
\hline 46 & $\mathrm{x}$ & $x$ & $x$ & & $x$ & $x$ & & 5 \\
\hline 47 & $x$ & & & & & $x$ & & 2 \\
\hline 48 & $x$ & & & & & & & 1 \\
\hline $\begin{array}{l}48 \\
49 \\
\end{array}$ & $x$ & & & & & & & 1 \\
\hline 50 & $x$ & $x$ & $x$ & $x$ & & $x$ & & 5 \\
\hline 51 & $x$ & & & & & & & 1 \\
\hline 52 & $\mathbf{x}$ & & $\mathbf{x}$ & $\mathrm{x}$ & & & & 3 \\
\hline 53 & $x$ & & & & & & & 1 \\
\hline 54 & $x$ & & & $x$ & & & & 2 \\
\hline 55 & $x$ & $x$ & & $x$ & $x$ & $x$ & & 5 \\
\hline 56 & $x$ & $x$ & & & & & & 2 \\
\hline 57 & $x$ & $x$ & & & $x$ & & & 3 \\
\hline 58 & & & $x$ & $x$ & & & & 2 \\
\hline 59 & $x$ & $x$ & $x$ & $x$ & & $x$ & & 5 \\
\hline & 45 & 36 & 28 & 27 & 25 & 22 & 3 & \\
\hline
\end{tabular}




\section{Results and discussion}

An overview of the collected 59 final articles shows that research on the sharing economy and fast fashion is incipient, emerging in recent years (Figure-2), and dispersed, spanning several research areas (Table-2).

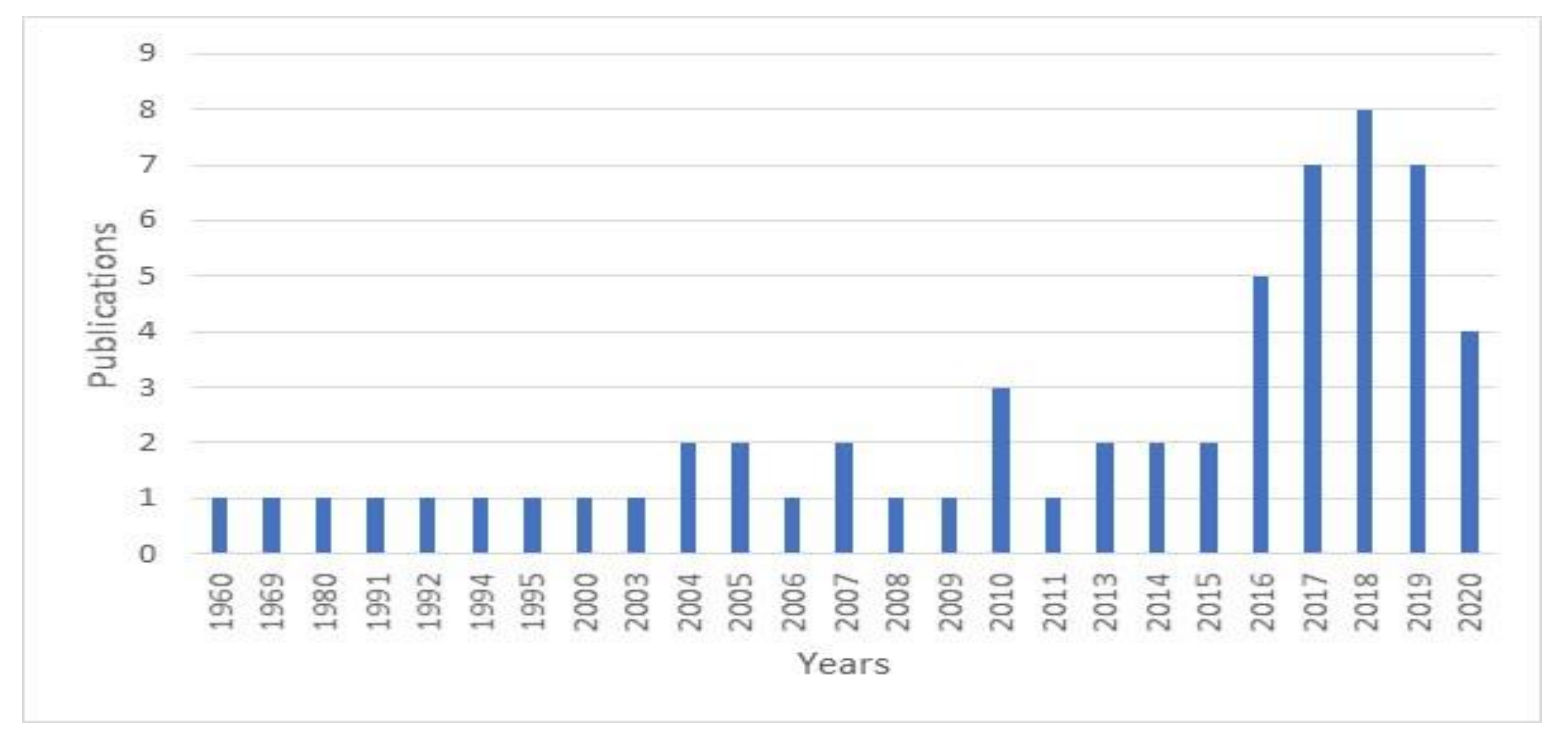

Figure: 2 - Search results by year

Initial finding on the review identify that the phenomenon of fast fashion is responsible for unsustainable production and consumption patterns, which is why a change in consumer behavior is necessary, and therefore, the application and consolidation of sharing economy networking platforms in the fashion industry (Joyner Armstrong \& Park, 2017) could have social, economic and environmental benefits.

An overview and analysis focused on the topics of fast fashion, the consumption of textile fashion, the specific context of the sharing economy and the consumer behavior have been found through the literature review (59 items), shown in this study (Table-3). The coded topics that these 59 selected articles talk about are (Figure-1): Behavior (45), Internet (36), Fashion (28), Sustainability (27), Ecommerce (25), Sharing (22), and COVID-19 (3), some articles contain up to 6 of these 7 topics, and most of them contain more than one topic.

As a global finding, from the information obtained in this review, it can be said that fashion and textile fashion consumption in the context of the sharing economy is becoming an area of interest for researchers. Existing contributions have been made to the factors that drive and hinder the acceptance of solutions. Some academic work has investigated the relationship between consumption and the sharing economy by exploring the nature, meanings, and dynamics of consumption in this context. In doing so, these documents have provided explanations of how consumers experience solutions, and the elements and conditions that enable them to contract and standardize practices that involve a transition to a more environmentally friendly economy.

Additionally, the analysis was also done with the intention of making an estimated approximation on the impact of the creation of sustainable value and consumer behavior. In this sense, it was observed that the "TPB" Theory of Planned Behavior (Ajzen, 1991) and the "DTPB" Decomposed Theory of Planned Behavior (Taylor \& Todd, 1995) are the reference theories to take into account to understand consumer behavior, although the latter mentioned (DTPB), is the one that best provides a way of 
understanding how the individual's attitude, subjective norm, and perceived behavioral control influence the repetition of behavior and the intention of individuals to accept new technological innovations.

As a research agenda, based on the number of publications mentioned above, the following points will be discussed below: a) in the categorization section, about the content of the seven assigned categories, and subsequently, b) in the applicable theories section, about the theories that appear to be recommended in consumer behavior for the context of this study.

\subsection{Categorization}

As mentioned above, the Content Analysis technique has been used to categorize the 59 items of the literature review; the items were selected and categorized following selection criteria based on keywords and phrases contained in the texts related to the purpose of the study and seven categories were established (Figure-2), which are detailed below.

\subsubsection{Behavior}

Understanding consumer behavior makes it possible to explain and predict human actions related to consumption: this is a fundamental issue for different types of organizations to design their communication strategies (Herrero, 2005). The study of human behavior facilitates the identification of the needs and desires of consumers (Corrons, 2018), thereby contributing to the fulfilment of the socio-economic objectives of organizations. The consumer's attitude also plays an important role, since a positive or affirmative attitude (Ajzen, 1991) towards the performance of a particular behavior strengthens the intention to perform the behavior.

Consumer behavior, decision-making, and their purchasing patterns have been the object of study and the basis of theories, which is now also essential to explain the use of social media platforms for the sharing economy. Changes in behavioral, normative and control beliefs can produce changes in intentions, and these changes in intentions are reflected in subsequent behavior (Ajzen, 1991; Corrons, 2018). The intention of consumers to visit a website depends on the sensation of enjoying it and on two beliefs (Ahn, Ryu, \& Han, 2007): ease of use and perceived usefulness. Likewise, the adoption of exchange systems by groups of individuals has as precursors a series of motivational, attitudinal, socio-normative and control factors (Ajzen, 2011; Corrons, 2018), and all of them condition the behavioral intention and, subsequently, the conduct itself.

Related to fashion, consumer behavior can make a difference by extending the life of clothing by sharing or reusing it. The action of reusing clothes by selling them through online platforms, giving them away to charities or friends has the environmental benefit of prolonging the useful life of the clothes instead of storing them in the back of the closet and not wearing them. Buying or exchanging a second-hand garment displaces the acquisition of a new one and significant environmental savings are achieved by avoiding producing, processing, and throwing it to landfills. Extending the useful life of products should be the first preference when taking actions to improve the sustainability of clothing (WRAP, 2017): "Sustainable online fashion is booming and the possibilities for the Internet to achieve it are enormous".

Some findings show that behavior towards the purchase of second-hand products seems to have the main driver for practical and economic reasons and less motivations for environmental reasons (Clausen, Blättel-Mink, Erdmann, et al., 2010). Another interesting finding is the existence of a preference for high-quality second-hand products over recently produced low-quality products (Clausen, Blättel-Mink, Erdmann, et al., 2010; Gullstrand Edbring, Lehner, \& Mont, 2016). Furthermore, some authors (Lee \& Chow, 2020) suggest that gender and previous experience, with fashion rental, significantly affect consumers' intentions to continue participating in online fashion rental, and it seems that women are the ones showing a greater intention to rent. 


\subsubsection{Internet}

The increase in Internet accessibility and the availability of smartphones has led to the new form of electronic word of mouth "EWOM" (Armelini, 2006; Matute Vallejo, Polo Redondo, \& Utrillas Acerete, 2015), and consequently, today's consumers, especially Millennials, " $81 \%$ use Internet regularly" (Matesa, 2021), are increasingly using online tools to sharing their opinions about the products and services they consume. The Millennial generation is now the largest consumer of goods, and their attention has shifted from traditional advertising methods, to being influenced (Chivandi, Olorunjuwon Samuel, \& Muchie, 2020) by new social media platforms and so-called "influencers".

Consumers increasingly sharing their experiences through social networks and, furthermore, innovations in social networks are tools that consumers use to provide and receive information (Chivandi, Olorunjuwon Samuel, \& Muchie, 2020). Likewise, the capabilities of social networks have been the forerunners of platforms such as YouTube, Facebook, Twitter, WhatsApp, and Pinterest, which have become a new and attractive way of disseminating sharing information in a globalized world.

The study of the widespread proliferation of online shopping and online consumer behavior in particular has become an important topic among researchers, as illustrated by the large number of publications in different fields, such as information systems, marketing, management and psychology (Cheung, Chan, \& Limayem, 2005; Hansen \& Moller, 2009; E. Y. Kim \& Kim, 2004; Y.-K. Kim, Kim, \& Kumar, 2003; Tong, 2010), and some of them already are based on clothing purchases.

Previous research shows that there are numerous factors that affect online consumer behavior, but, there are mixed findings in the literature and many factors that influence online consumer buying behavior that have not yet been explored, especially considering the dynamics of technology and consumer needs, which are constantly evolving (Herrero \& Rodríguez del Bosque, 2008; Katz, 1960; Luque-Martínez, Castañeda-García, Frías-Jamilena, et al., 2007). However, "online consumer behavior" is a key variable in consumer behavior research to explain this behavior, highlighting its multidimensional aspect constituted by "emotional (affective)", "assessment (cognitive)" and "tendency to act (conative)".

\subsubsection{Fashion}

Fashion products are multifunctional and of high social value for people, but this value is not derived only from the satisfaction of basic or utilitarian needs, such as providing warmth or protection (Heuer $\&$ Becker-Leifhold, 2018). Fashion products also provide other functions that are much more valuable as a result of their ability to satisfy hedonistic and psychogenic needs and desires (Heuer \& BeckerLeifhold, 2018; Solomon, 2004). The "hedonic value" could be one of the motivational factors of the consumer to use virtual networks of sharing economy: need for experience that entails emotional responses or fantasies (Miller, 2013; Schwartz, 1992, 1994; Solomon, 2004). For example, through the "Rent-the-Runway" website (Renttherunway, 2020), access is provided to designer clothing that would be financially out of reach for many consumers. This platform facilitates access to luxury items that they could not afford under normal conditions, and allows the consumer to pretend what they are not for a day and do something that they could not otherwise do (Benoit, Baker, Bolton, et al., 2017), and therefore helps the consumer to satisfy their desire to seek more social status.

The shift towards new ownership models in fashion, according to the McKinsey Fashion Status Report (McKinsey\&Company, 2019), is driven by the consumer's growing desire for variety, sustainability and affordability, and there are sources suggesting that the "resale market" could be larger than the fast fashion market in ten years. This trend is driven in part by the young generation's desire for novelty, while encompassing sustainability, which is clearly a key evolution in consumer behavior and is expected to have an impact on the fashion business in the next few years.

Fashion in general is being highly criticized (Linden, 2016; Mora \& Rouzaut, 2018), ranking it among the most polluting industries in the world for its excessive consumption of natural resources and raw materials, generating high levels of pollution and waste, which leaves a significant carbon footprint. 
Particularly when it comes to fast fashion (Linden, 2016). In addition to applying what is related to fashion in general, it also generates serious human rights problems, since mass production affects the poor working conditions of many people, especially in underdeveloped countries.

\subsubsection{Sustainability}

The fashion and clothing industry is the second largest consumer of water in the world, behind the energy industry, and is classified as an environmental emergency given the negative impact on the environment, health and development of the planet (Moda.es, 2018; UNECE, 2018):

- A 2.5 trillion dollars industry (producing a cotton shirt requires the amount of water a person drink in 2.5 years).

- Produce $20 \%$ of wastewater and $10 \%$ of $\mathrm{CO} 2$ emissions globally. More emissions than all international flights and the shipping of goods together.

- $73 \%$ of garments globally end up in landfills.

- $85 \%$ of total textiles are sent to landfills (21 billion tons a year).

- Cotton cultivation is responsible for $24 \%$ of insecticides and $11 \%$ of pesticides, although it uses only $3 \%$ of the world's arable land.

- It is responsible of Gender labor issues and poverty. One in six people in the world work in a fashion-related job, and $80 \%$ of the workforce throughout the supply chain is women.

Plastic waste and climate change are considered the most important environmental problems (ING, 2019), although the variations in opinions between countries suggest that local conditions influence attitudes. Some relevant data from the ING report (ING, 2019) show that in Europe 67\% of Europeans think that the most important problems are plastic waste $(34 \%)$ and climate change $(33 \%)$. Very similar figures are given in the US and Australia: in the US plastic waste (29\%) and climate change (34\%) represent 63\%, and in Australia plastic waste (34\%) and climate change (34\%) represent 68\%.

An issue that generates discussion is that although behavioral changes support ecology, to carry them out requires a complex revolution and coordination (ING, 2019). For some people, an economic incentive could increase recycling, while for others, protecting the environment is already a great incentive and, in addition, local factors (or beliefs) such as social and cultural norms can also influence attitudes. Many say they are already reusing or have in mind to reuse broken or damaged products, and most expect to change their behavior in the next three years, recognizing that the current level of consumption is unsustainable.

\subsubsection{Ecommerce}

E-commerce, digital advertising, and interactions through social networks are changing consumer behavior, decision-making processes, influences and the way brands position themselves (Barrullas, 2016). Online markets and technologies applied to social networks improve the exchange of resources between people who can be both sellers and buyers (Joyner Armstrong \& Park, 2017). There is no doubt that the digital revolution is one of the most important influences on consumer behavior (Barrullas, 2016), and that the impact of the Internet will continue to spread as an increasing number of people around the world connecting and start shopping online.

Technological tools are driving this advance by considerably reducing transactional costs, facilitating the sharing of resources through digital platforms, that combine e-commerce with the elements of social networks and word of mouth (Joyner Armstrong \& Park, 2017). This emerging digital economy has been driven in part by great concern about the ecological and social impacts of consumption because sharing resources is seen as more sustainable than buying and hoarding.

\subsubsection{Sharing}

The adoption of the sharing economy by a group of individuals has as precursors a series of attitudinal, socio-normative and control factors (Lang \& Joyner Armstrong, 2018; Taylor \& Todd, 1995), which condition the behavioral intention and the conduct itself. In particular, the intention to carry out transactions in this type of network is directly (Taylor \& Todd, 1995) determined by the attitude of 
individuals towards their use, the regulatory influence of third parties and the control or domain to develop this behavior.

The garment reused principle is mentioned repeatedly, referring to producing less new products to reduce or avoid waste altogether. Therefore, a central principle of the sharing economy is also identified, "buying less and sharing more", which does not necessarily mean consuming less (Botsman \& Rogers, 2010), and it is also in line with the circular economy: do not throw clothes that other people can use and do not leave unused clothes in the closet, give a second life to these clothes. In addition, some aspects related to resource efficiency, business opportunities, sustainability, social contact, social cohesion, and the economy have also been evidenced.

Sharing economy must act in symbiosis with the "circular economy" to replace the current linear economy. It should be remembered that the linear shape begins with a product design and development idea at one end and closes when the product ends up as waste and is incinerated at the other end, "disposable culture" (Skytte, 2014), and are often non-degradable or recyclable products.

The ING report (ING, 2015) on the sharing economy, highlights that the possibility of saving money strongly influences the participation of people in Europe (58\%), the United States (55\%) and Australia (45\%). Saving money has the highest number of people saying it is an influencer in all 15 countries surveyed, and the view that it is good for the environment also influences all countries. Many respondents see the exchange as "an easy way to earn extra money", while helping to build communities seems to be less attractive for most countries, but it is quite important in Turkey (65\%), Poland (59\%) and Italy (58\%). The report also highlights "that these views hold much more among those who already share than among those who do not. The view that sharing builds communities is particularly influential for those who share, as $73 \%$ say it is important compared to the $39 \%$ of those who do not share".

\subsubsection{COVID-19}

Culture and the economy in times of crisis (Castells et al., 2017) predispose people's attitude towards relational social practices and alternative economies: "Motivational attitudes are more important than sociodemographic variables when explaining the predominant orientation towards relational and / or social practices". Currently COVID-19 is influencing this aspect: The situation generated by the pandemic, its consequent confinement, the state of alarm and the limitations of movement that it has implied, have led to new social habits around the world related to the usage of technology, and also generating an incredible increase in e-commerce and Internet transactions (Inforges, 2020). "The impact of the coronavirus has increased the consumption of products through the Internet by up to 62\%" (Murciaeconomía, 2020). Those who saw digital commerce as a secondary channel are now forced to reorienting all their activities and change their way of thinking (Accenture, 2020): "The pandemic has increased the use of the electronic transactions, and now it is an opportunity to expand the current offer and create new lines of service".

\subsection{Applicable theories}

As mentioned in the previous section, consumer behavior has been the object of study and the basis of some theories to explain the use of social media platforms for the sharing economy. Consumer behavior can be influenced by many variables: the beliefs, the feeling of enjoyment, the feeling of ease of use and the perceived usefulness, which among others are factors that can influence to have a positive or affirmative attitude towards the performance of a consumer behavior, but could also be influenced by the economic situation, the benefits that can be obtained and the conditions of local factors (such as social and cultural norms).

Some researchers rely on the (TPB) Theory of Planned Behavior (Ajzen, 1991) as a theoretical framework to analyze the determinants of consumers' intention to adopt the sharing economy through 
the rental and exchange of clothes (Lang \& Joyner Armstrong, 2018). Attitude towards behavior and control of perceived behavior are considered the "personal factors", while the subjective norm is identified as "social factor" (Ajzen, 1991). Attitudinal elements, behavioral beliefs, evaluation of results, also represent, respectively, personal and social variables involved in behavior towards the sharing economy (Lang \& Joyner Armstrong, 2018). According to TPB, it is assumed that behavioral intention is influenced by the joint effect of attitude, subjective norms and behavior control (Ajzen, 1991): -"The attitude" of an individual towards the performance of a specific behavior is related to beliefs that the performance of the behavior will lead to certain results. - "Subjective norms" are the individual's perception of the social pressures that are imposed on him to exercise the behavior in question. - "Perceived behavior control" reflects the perceived ease or difficulty in performing a certain behavior.

The TPB has been shown to account for a wide range of consumer behaviors, and in addition the components of TPB capture the main determinants to explain and predict behavior in the context of the sharing economy (Roos \& Hahn, 2017). However, in the case of the use of virtual platforms in the context of the sharing economy, the - "Decomposed Theory of Planned Behavior (DTPB)" - is more appropriate (Figure-3), since it better explains the intention to carry out "virtual transactions" (considering them as technological innovations): in this type of exchange, the intention is determined by the attitude of the individuals, the normative influence of third parties and the control or domain to develop this behavior (Taylor \& Todd, 1995), and also, each of these factors (Ajzen, 2011; Corrons, 2018) is determined by beliefs, perceptions and personal values or motivational factors.

The DTPB, as shown in Figure-3, is used to answer that the adoption of the sharing economy by a group of individuals has attitudinal precursors, social regulations, and control, and that these factors condition the intention of the behavior and the behavior itself. Therefore, the intention to carry out transactions in this type of virtual networks is directly determined by the attitude of individuals towards its use, the regulatory influence of third parties, the control or domain for develop this behavior (Corrons, 2018) and also allows the understanding of behavioral repetitions. So "DTPB has better predictive power than TPB" (Taylor \& Todd, 1995).

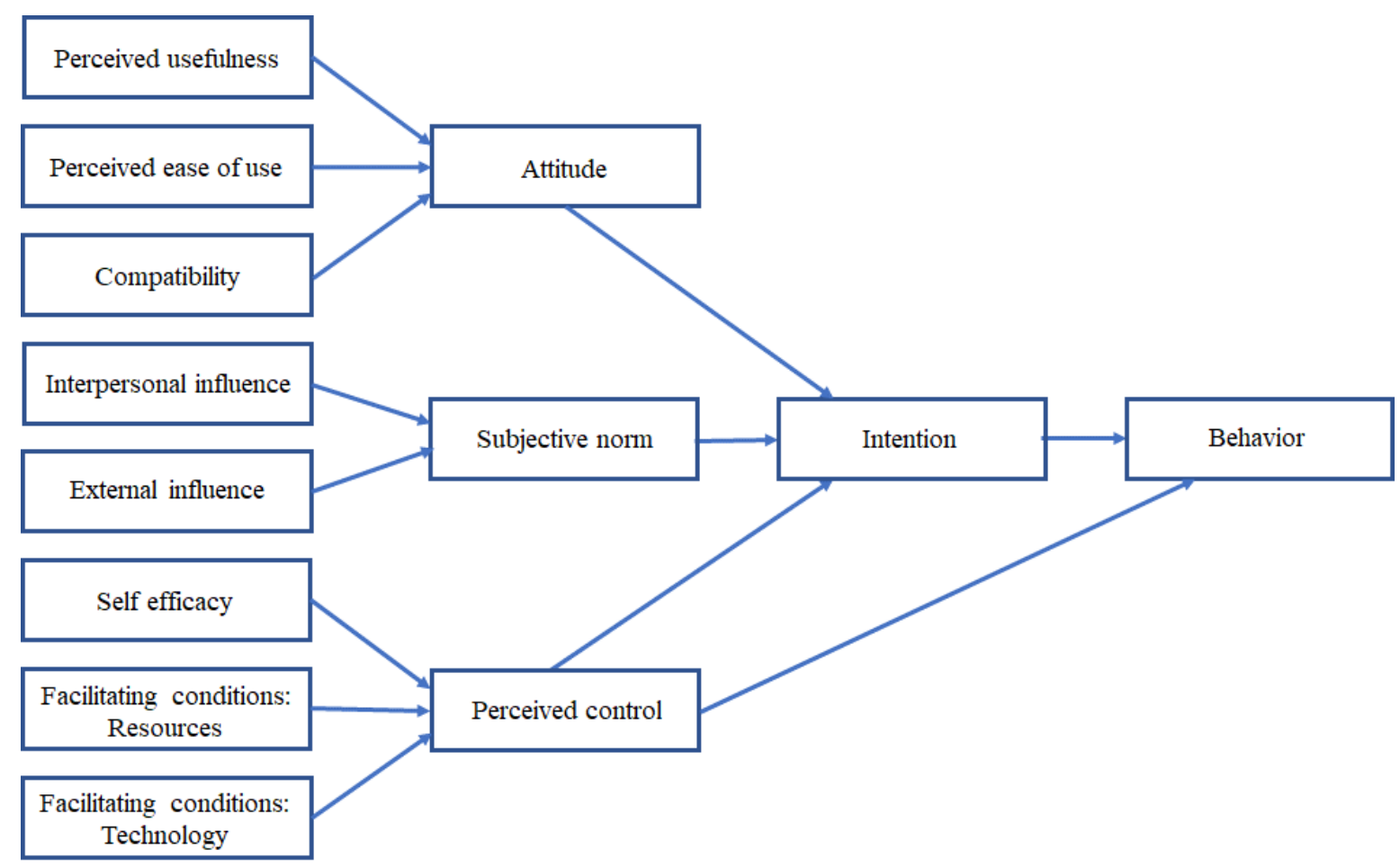

Figure: 3 - Decomposed Theory of Planned Behavior (DTPB) by (Taylor \& Todd, 1995) 
The relevance of understanding the impacts on consumer behavior of fashion products has grown as participation in online communities and social networks continues to be popular for fashion (Nash, 2018): "they are online communities that are based on the capacity of new technologies to create and facilitate platforms where consumers can carry out sharing behaviors". Additionally, the use of social media platforms (Chivandi, Olorunjuwon Samuel, \& Muchie, 2020; Nash, 2018) can be described as the new wave of information and communication technology. Consequently, theories and predictions are important to better understand consumer behavior and analyze the determinants and beliefs that influence their intentions.

\section{Conclusions}

The literature about the subject of this study is recent, and much of the work being done in this regard is still exploratory and definitions are still emerging. This study analyzed research articles published in academic journals, but also from some universities, insights from trade journal websites, press releases, books, articles from auditors and surveys of prestigious companies, as well as e-commerce websites, among others.

The review of the existing literature reveals opportunities for the development, extension and testing of theories in areas such as the sharing economy, the sustainability of fast fashion and the behavior of the virtual consumer of second-hand clothing.

The results of analyzing the content of the 59 items selected and grouped into 7 categories show that consumers' values, attitudes, perceptions, and social norms, as social psychological factors, are important prerequisites for the transition to sustainable behavior (P. C. Stern, 2000). Likewise, a greater concern of consumers for the environment and for others could improve their attitude towards sustainable behavior, and stronger would be the expectations of others and the moral obligation to behave sustainably. This effect will cause more consumers to switch from unsustainable behavior to more sustainable behavior (Roos \& Hahn, 2017). The more favorable the attitude towards a behavior, the more likely is the performance of the behavior (Ajzen, 1991). The more consumers engage in sharing consumption behavior, the more altruistic they become over time (Roos \& Hahn, 2017). For some people, non-ownership and transfer of ownership (Belk, 2014) may reflect their personal values in the pursuit of access-based consumption.

The consumer with their behavior can make a difference by helping to extend the useful life of their possessions, since the reuse of clothing by selling it through online platforms, donating it to charities or giving it to friends has the environmental benefit of extending its useful life (Gullstrand Edbring, Lehner, \& Mont, 2016), and is better than storing it in the closet and not using it. Buying or exchanging a second-hand garment helps to displace acquiring a new one and helps achieve significant environmental savings by avoiding production, processing, and subsequent disposal. Extending the useful life of clothing should be considered the first preference when taking measures that improve sustainability. A circumstance that is being favored since the online exchange of sustainable fashion is increasing and the Internet offers more and more possibilities for its expansion.

The limitations of this work are recognized, since there are many factors that influence online consumer behavior that have not yet been explored, especially considering the dynamics of technology and consumer needs, which are constantly evolving. As it is a limited literature review work, it could have continuity in conducting a deeper investigation and could be used this study as contextualization to focus about other future studies, which could be based on the details highlighted in this work on the importance of people's behavior towards a more sustainable economy, emphasizing the sharing economy and fast fashion through virtual networks. 
The future of research in this area must bring together social, economic, and technological research to provide a more holistic understanding. The value of this contribution is to establish a common framework for discussion, within which the research has been carried out, since there is still much to analyze about consumer behavior in this context. Future research can analyze other scenarios and impacts on sustainability and consumer behavior, using other approaches, and can map existing exchange platforms, isolating platform type and shared practice attributes to establish business patterns or models and their viability. It is desirable that sustainability and the need for more sustainable consumption are a motivating influence for future research on the sharing economy related to fast fashion and virtual consumer behavior. 


\section{References}

Abela, J. A. (2002). Las técnicas de Análisis de Contenido: Una revisión actualizada (Content Analysis Techniques: An Updated Review). Fundación Centro de Estudios Andaluces, 34.

Accenture. (2020). Covid-19: Cómo actuar hoy, qué hacer mañana. Cambio de canal: priorizando el e-commerce. Gestionando el impacto económico y humano del COVID-19 (Covid-19: How to act today, what to do tomorrow. Channel change: prioritizing e-commerce. Managing the economi. https://www.accenture.com/_acnmedia/Thought-Leadership-Assets/PDF2/Accenture-COVID-19-Channel-Shift-Prioritizing-Digital-Commerce-ES.pdf

Ahn, T., Ryu, S., \& Han, I. (2007). The impact of Web quality and playfulness on user acceptance of online retailing. Information and Management, 44(3), 263-275. https://doi.org/10.1016/j.im.2006.12.008

Ajzen, I. (1991). Theory of planned behavior. Organizational Behavior and Human Decision Processes, 50, 179-211. http://www.nottingham.ac.uk/ ntzcl1/literature/tpb/azjen2.pdf

Ajzen, I. (2011). The theory of planned behaviour: Reactions and reflections. Psychology \& Health, 26(9), 1113-1127. https://doi.org/10.1080/08870446.2011.613995

Ajzen, I., \& Fishbein, M. (1980). Understanding attitudes and predicting social behavior. In Journal of Experimental Social Psychology (p. 278). Prentice-Hall.

Armelini, G. (2006). Internet convierte el boca-oreja en el eWom, una poderosa herramienta de marketing $\mid$ Informes $\mid$ Mundo digital $\mid$ Computing (Internet turns word of mouth into eWom, a powerful marketing tool $\mid$ Reports $\mid$ Digital world $\mid$ Computing). Computing.Es.

http://www.computing.es/mundo-digital/informes/1012944046601/internet-convierte-bocaoreja-ewom.1.html

Barrullas, J. (2016). El comportamiento del consumidor y las nuevas tendencias de consumo ante las TIC (Consumer behavior and new consumer trends in the face of ICT). UOC - Blog d'Economia i Empresa. https://economia-empresa.blogs.uoc.edu/es/consumidor-y-tendenciasconsumo-ticl

Bates, M. J. (1976). Rigorous Systematic Bibliography. RQ, 16(1), 7-26. http://www.jstor.org/stable/41354519

Belk, R. (2014). You are what you can access: Sharing and collaborative consumption online. Journal of Business Research, 67(8), 1595-1600. https://doi.org/10.1016/j.jbusres.2013.10.001

Benoit, S., Baker, T. L., Bolton, R. N., Gruber, T., \& Kandampully, J. (2017). A triadic framework for collaborative consumption (CC): Motives, activities and resources \& capabilities of actors. Journal of Business Research, 79(May), 219-227. https://doi.org/10.1016/j.jbusres.2017.05.004

Botsman, R., \& Rogers, R. (2010). Whats mine is yours: the rise of collaborative consumption. Harpers Collins e-books.

Cabero, J., Loscertales, F., Aguaded, J. I., Barroso, J., Cabero, A., Domene, S., Duarte, A., Fería, A., Núñez, T., Román, P., \& Romero, R. (2015). Elaboración de un sistema categorial de análisis de contenido para analizar la imagen del profesor y la enseñanza en la prensa (Development of a categorical content analysis system to analyze the image of the teacher and teaching in the press). https://idus.us.es/xmlui/bitstream/handle/11441/24794/elaboracion.pdf?sequence=1

Camacho-Moya, V. (2017). La Influencia Del Marketing Digital En Los Millennials Mexicanos 
Para Fomentar El Consumismo De Moda Rápida (The Influence Of Digital Marketing On Mexican Millennials To Promote Fast Fashion Consumerism). Universidad de Guadalajara, December. https://doi.org/10.13140/RG.2.2.14667.49441

Cameron, J. (2015). Clothing Poverty: The Hidden World of Fast Fashion and Second-Hand Clothes. Australian Feminist Studies, 30(85), 316-320. https://doi.org/10.1080/08164649.2015.1107949

Cañigueral, A. (2013). Chicfy marketplace para vender tu ropa y comprarla a otras chicas (Chicfy marketplace to sell your clothes and buy them from other girls). Consumocolaborativo.Com. http://www.consumocolaborativo.com/2013/02/17/convierte-tu-armario-en-una-boutiqueonline-con-chicfy/

Cañigueral, A. (2016). Hacia una economía colaborativa «responsable» (Towards a "responsible" sharing economy). Universitat Oberta de Catalunya, 16-27. http://oikonomics.uoc.edu

Castells et al., M. (2017). Otra economía es posible : cultura y economía en tiempo de crisis / Manuel Castells et al. ; traducción de Fernacisco Muñoz de Bustillo (Another economy is possible: culture and economy in times of crisis / Manuel Castells et al. ; translation by Francisc. Madrid : Alianza Editorial.

Cheung, C. M. K., Chan, G. W. W., \& Limayem, M. (2005). A Critical Review of Online Consumer Behavior. Journal of Electronic Commerce in Organizations, 3(4), 1-19. https://doi.org/10.4018/jeco.2005100101

Chivandi, A., Olorunjuwon Samuel, M., \& Muchie, M. (2020). Social Media, Consumer Behavior, and Service Marketing. In Consumer Behavior and Marketing. IntechOpen. https://doi.org/10.5772/intechopen.85406

Clausen, J., Blättel-Mink, B., Erdmann, L., \& Henseling, C. (2010). Contribution of Online Trading of Used Goods to Resource Efficiency: An Empirical Study of eBay Users. Sustainability, 2(6), 1810-1830. https://doi.org/10.3390/su2061810

Corrons, A. (2018). Análisis de la influencia de los valores humanos y las actitudes en el proceso de adopción de redes virtuales de intercambio no monetario (Influence of human values and attitudes in the process of adopting virtual networks of non-monetary exchange) [Universitat Jaume I]. https://doi.org/10.6035/14115.2018.529582

Crossan, M. M., \& Apaydin, M. (2010). A Multi-Dimensional Framework of Organizational Innovation: A Systematic Review of the Literature. Journal of Management Studies, 47(6), 1154-1191. https://doi.org/10.1111/J.1467-6486.2009.00880.X

Duff, C. (2019). First Cars, Now Clothing? Fashion in the Sharing Economy - Apparel Textile Sourcing Trade Shows: Apparel Textile Sourcing. https://www.appareltextilesourcing.com/sharing-economy/

Guix Oliver, J. (2008). El análisis de contenidos: ¿Qué nos están diciendo? (Content analysis: What are they telling us?). Revista de Calidad Asistencial, 23(1), 26-30. https://doi.org/10.1016/S1134-282X(08)70464-0

Gullstrand Edbring, E., Lehner, M., \& Mont, O. (2016). Exploring consumer attitudes to alternative models of consumption: Motivations and barriers. Journal of Cleaner Production, 123, 5-15. https://doi.org/10.1016/j.jclepro.2015.10.107

Hansen, T., \& Moller, J. (2009). Shopping orientation and online clothing purchases: the role of gender and purchase situation. European Journal of Marketing, 43(9/10), 1154-1170. https://doi.org/10.1108/03090560910976410 
Herrero, A. (2005). El proceso de adopción de nuevos sistemas de venta: aplicación al comercio electrónico entre particulares y empresas (The process of adopting new sales systems: application to electronic commerce between individuals and companies) [Universidad de Cantabria]. In Tesis Doctoral. Universidad de Cantabria. Departamento de Administración de Empresas.

https://www.researchgate.net/publication/279685086_El_proceso_de_adopcion_de_nuevos_sis temas_de_venta_aplicacion_al_comercio_electronico_entre_particulares_y_empresas

Herrero, A., \& Rodríguez del Bosque, I. (2008). The effect of innovativeness on the adoption of B2C e-commerce: A model based on the Theory of Planned Behaviour. Computers in Human Behavior, 24(6), 2830-2847. https://doi.org/10.1016/j.chb.2008.04.008

Heuer, M., \& Becker-Leifhold, C. (2018). Eco-friendly and fair : fast fashion and consumer behaviour. In M. Heuer \& C. Becker-Leifhold (Eds.), The Textile Institute. Routledge - Taylor \& Francis Group. https://learning.oreilly.com/library/view/eco-friendly-andfair/9781351058339/?ar

Heuritech, \& Gosselin, V. (2019). When the sharing economy is challenging fast fashion. Heuritech.Com. https://www.heuritech.com/blog/articles/sharing-economy-fast-fashion/

Inforges. (2020). El ecommerce en tiempos del COVID-19 (Ecommerce in times of COVID-19). Inforges.Es. https://www.inforges.es/post/ecommerce-en-tiempos-del-covid-19

ING. (2015). European sharing economy to grow by a third in the next 12 months. ING International Survey. https://www.ing.com/Newsroom/News/European-sharing-economy-togrow-by-a-third-in-the-next-12-months.htm

ING. (2019). Circular economy : Consumers seek help. ING International Survey, November. https://think.ing.com/uploads/reports/IIS_Circular_Economy_report_FINAL.PDF

Joyner Armstrong, C. M., \& Park, H. (2017). Sustainability and collaborative apparel consumption: putting the digital 'sharing' economy under the microscope. International Journal of Fashion Design, Technology and Education, 10(3), 276-286. https://doi.org/10.1080/17543266.2017.1346714

Katz, D. (1960). The Functional Approach to the Study of Attitudes. Oxford University - Public Opinion Quarterly, 24(2, Special Issue: Attitude Change), 163. https://doi.org/10.1086/266945

Kim, E. Y., \& Kim, Y.-K. (2004). Predicting online purchase intentions for clothing products. European Journal of Marketing, 38(7), 883-897. https://doi.org/10.1108/03090560410539302

Kim, Y.-K., Kim, E. Y., \& Kumar, S. (2003). Testing the Behavioral Intentions Model of Online Shopping for Clothing. Clothing and Textiles Research Journal, 21(1), 32-40. https://doi.org/10.1177/0887302X0302100104

Lang, C., \& Joyner Armstrong, C. M. (2018). Collaborative consumption: The influence of fashion leadership, need for uniqueness, and materialism on female consumers' adoption of clothing renting and swapping. Sustainable Production and Consumption, 13(November), 37-47. https://doi.org/10.1016/j.spc.2017.11.005

Lee, S., \& Chow, P.-S. (2020). Investigating consumer attitudes and intentions toward online fashion renting retailing. Journal of Retailing and Consumer Services, 52, 101892. https://doi.org/10.1016/j.jretconser.2019.101892

Linden, A. R. (2016). An Analysis of the Fast Fashion Industry. Bard Digital Commons. http://digitalcommons.bard.edu/senproj_f2016/30

Luque-Martínez, T., Castañeda-García, J. A., Frías-Jamilena, D. M., Muñoz-Leiva, F., \& 
Rodríguez-Molina, M. A. (2007). Determinants of the Use of the Internet as a Tourist Information Source. The Service Industries Journal, 27(7), 881-891.

https://doi.org/10.1080/02642060701570586

MacArthur, E. (2017). A new textiles economy: redesigning fashion's future. In Ellen Macarthur Foundation. https://www.ellenmacarthurfoundation.org/assets/downloads/publications/ANew-Textiles-Economy_Full-Report_Updated_1-12-17.pdf

Matesa, D. (2021). CONSUMIDOR ONLINE 2021: Comportamiento, perfil y características (ONLINE CONSUMER 2021: Behavior, profile and characteristics).

Expertosnegociosonline.Com. https://www.expertosnegociosonline.com/comportamientoconsumidor-online/

Matute Vallejo, J., Polo Redondo, Y., \& Utrillas Acerete, A. (2015). Las características del bocaoído electrónico y su influencia en la intención de recompra online (The characteristics of electronic mouth-to-ear and its influence on online buyback intention). Revista Europea de Direccion y Economia de La Empresa, 24(2), 61-75. https://doi.org/10.1016/j.redee.2015.03.002

McKinsey\&Company. (2019). The State of Fashion 2020. https://www.mckinsey.com/ /media/McKinsey/Industries/Retail/Our Insights/The State of Fashion 2019 A year of awakening/The-State-of-Fashion-2019-final.ashx

Miller, K. (2013). Hedonic customer responses to fast fashion and replicas. Journal of Fashion Marketing and Management, 17(2), 160-174. https://doi.org/10.1108/JFMM-10-2011-0072

Moda.es. (2018). La ONU califica la industria del 'fast fashion' como "emergencia medioambiental" (The UN describes the "fast fashion" industry as an 'environmental emergency'). Modaes.Es. https://www.modaes.es/back-stage/la-onu-califica-la-industria-delfast-fashion-como-emergencia-medioambiental.html

Mora, E., \& Rouzaut, N. (2018). El impacto de la moda, un desafio para la agenda de la industria textil (The impact of fashion, a challenge for the textile industry agenda). Universidad de Navarra. https://www.unav.edu/web/vida-universitaria/detallenoticiapestania/2018/02/04/elimpacto-de-la-moda-un-desafio-para-la-agenda-de-la-industria-textil articleId=17078211

Murciaeconomía. (2020). La importancia del eCommerce durante el Covid-19 (The importance of eCommerce during Covid-19). MurciaEconomía.Com.

https://murciaeconomia.com/art/69327/la-importancia-del-ecommerce-durante-el-covid-19

Nash, J. (2018). Exploring how social media platforms influence fashion consumer decisions in the UK retail sector. Journal of Fashion Marketing and Management, 23-1, 82-103. https://doi.org/10.1108/JFMM-01-2018-0012

Renttherunway. (2020). Rent the Runway - Rent Designer Dresses, Apparel \& Accessories. Renttherunway.Com. https://www.renttherunway.com/

Roos, D., \& Hahn, R. (2017). Does shared consumption affect consumers' values, attitudes, and norms? A panel study. Journal of Business Research, 77(April), 113-123. https://doi.org/10.1016/j.jbusres.2017.04.011

Schwartz, S. H. (1992). Universals in the content and structure of values: Theoretical advances and empirical tests in 20 countries. Advances in Experimental Social Psychology, 25(C), 1-65. https://doi.org/10.1016/S0065-2601(08)60281-6

Schwartz, S. H. (1994). Are There Universal Aspects in the Structure and Contents of Human Values? Journal of Social Issues, 50(4), 19-45. https://doi.org/10.1111/j.15404560.1994.tb01196.x 
Skytte, C. (2014). THE COMSUMER - Sharing Economy in Denmark (SkytsEngel - e-book (ed.)). www.resecond.com

Solomon, M. R. (2004). Consumer Psychology. In Encyclopedia of Applied Psychology (pp. $483-$ 492). Elsevier. https://doi.org/10.1016/B0-12-657410-3/00219-1

Sorensen, \& Johnson Jorgensen. (2019). Millennial Perceptions of Fast Fashion and Second-Hand Clothing: An Exploration of Clothing Preferences Using Q Methodology. Social Sciences, 8(9), 244. https://doi.org/10.3390/socsci8090244

Stebbins, R. A. (1969). Studying the Definition of the Situation: Theory and Field Research Strategies. Canadian Review of Sociology, 6(4), 193-211. https://doi.org/10.1111/j.1755618X.1969.tb02309.x

Stern, E. (2017). Individual differences in the learning potential of human beings. Npj Science of Learning 2017 2:1, 2(1), 1-7. https://doi.org/10.1038/s41539-016-0003-0

Stern, P. C. (2000). New Environmental Theories: Toward a Coherent Theory of Environmentally Significant Behavior. Journal of Social Issues, 56(3), 407-424. https://doi.org/10.1111/00224537.00175

Sutherland, W., \& Jarrahi, M. H. (2018). The sharing economy and digital platforms: A review and research agenda. International Journal of Information Management, 43(September), 328-341. https://doi.org/10.1016/j.ijinfomgt.2018.07.004

Taylor, S., \& Todd, P. A. (1995). Understanding Information Technology Usage: A Test of Competing Models. Information Systems Research, 6(2), 144-176. http://0www.jstor.org.cataleg.uoc.edu/stable/23011007

Tong, X. (2010). A cross-national investigation of an extended technology acceptance model in the online shopping context. International Journal of Retail \& Distribution Management, 38(10), 742-759. https://doi.org/10.1108/09590551011076524

Tranfield, D., Denyer, D., \& Smart, P. (2003). Towards a Methodology for Developing EvidenceInformed Management Knowledge by Means of Systematic Review. British Journal of Management, 14(3), 207-222. https://doi.org/10.1111/1467-8551.00375

UNECE. (2018). Fashion and the SDGs: what role for the UN? UNECE.Org, 2. https://doi.org/10.1007/s11576-007-0062-1

Webster, J., \& Watson, R. T. (2002). Analyzing the Past to Prepare for the Future: Writing a Literature Review. MIS Quarterly, 26(2), xiii-xxiii. http://www.jstor.org/stable/4132319

WRAP. (2017). Valuing Our Clothes: the cost of UK fashion. Wrap.Org, July, 54. http://www.wrap.org.uk/sites/files/wrap/valuing-our-clothes-the-cost-of-ukfashion_WRAP.pdf

Yang, S., Song, Y., \& Tong, S. (2017). Sustainable retailing in the fashion industry: A systematic literature review. In Sustainability (Switzerland) (Vol. 9, Issue 7). MDPI AG. https://doi.org/10.3390/su9071266 